\title{
The Global Career of Indian Opium and Local Destinies
}

Amar Farooqui

Department of History, University of Delhi, Delhi amarfarooqui@ hotmail.com

\begin{abstract}
As is well known, opium was a major colonial commodity. It was linked to trade in several other commodities of the modern era such as tea, sugar and cotton and through these to Atlantic the slave trade. The movement of these commodities across continents shaped capitalism in very specific ways. In the case of India, for instance, earnings from the several components of the opium enterprise played an important role in the growth of industrial capitalism. This paper looks at the historical circumstances in which various localities and regions of the Indian subcontinent, especially western India, and the Indian Ocean became part of the opium enterprise during the early nineteenth century. It attempts to understand the manner in which local destinies were linked to the global, reinforcing and/or resisting British imperial interests. For this purpose I have chosen the port of Daman, on the West Coast of India as a representative example. Daman (Damaõ) was a Portuguese colony. The paper pays close attention to political processes at the local level so as to make sense of global patterns of trade in a commodity that was vital for sustaining the British Empire.
\end{abstract}

Keywords: Opium, Malwa, Daman, Smuggling, Estado da Índia, Macau, Bombay, Tea, East India Company, colonial commodities 
Colonial commodities created conditions that can be better understood in a global context and by scrutinizing the interconnections between developments in different parts of the world. As is well known, opium was a major colonial commodity. It was linked to trade in several other commodities of the modern era such as tea, sugar, cotton, and slaves. The movement of these commodities across continents shaped capitalism in very specific ways. In the case of India, for instance, earnings from the several components of the opium enterprise played a vital role in the growth of industrial capitalism in western India.

This paper looks at the historical circumstances in which the western and central regions of the Indian subcontinent became part of the global opium enterprise during the early nineteenth century. It attempts to understand the manner in which local destinies were linked to the global, reinforcing and/or resisting British imperial interests. Opium emerged as the leading commodity linking the Indian subcontinent with the commercial worlds of the Indian Ocean, the East, and Southeast Asia.

One would like to underline that close attention needs to be paid to processes at the local level so as to make sense of global patterns of trade in key colonial commodities. In the case of the sea-borne trade in Indian opium (as distinct from the internal trade in the commodity), it is necessary to examine the specific historical circumstances in which each of the several segments of the trade came to be part of a vast network exchanges: from producing areas of the interior located in the princely states ('native states' in British colonial terminology) of western and central India, to Portuguese colonial possessions on the West Coast (Konkan and Gujarat), and thence across the Indian Ocean to Macau and Canton. In this context the position of Indo-Portuguese business groups, strategically located along the West Coast, was historically significant. Unfortunately, this is a problem that has not received much attention. Indo-Portuguese business groups were key players in developing a network of trade that encompassed western and central India, Bombay (now Mumbai), Daman, Diu, Goa, Sind Macau and Canton. The massive expansion of opium exports from Bengal to China in the closing decades of the eighteenth century drew IndoPortuguese and Indian traders to the opium produce of princely states located in western 
and central India'. The state of Gwalior, located in central India, ruled by the Sindia dynasty, emerged as the largest supplier of the drug to private exporters operating on the West Coast. The long association of Indo-Portuguese traders with the sea-borne commerce of the West Coast, combined with the links they had with the Portuguese at Macau who aided in smuggling the drug into China, gave them a distinct advantage.

The traders of the Portuguese settlements in Konkan and Gujarat thus opened up new opportunities for the economies of the landlocked princely states of the Malwa plateau. The Malwa plateau was one of the two major opium-producing zones in the Indian subcontinent during the eighteenth and nineteenth centuries. Access to the sea via Portuguese settlements, especially Daman, had important implications for the princely states in terms of the manner in which they negotiated with British colonialism. The stability and autonomy of the Gwalior state, for instance, down to the 1840s (even as it acknowledged British supremacy) is largely to be attributed to the success of the West Coast opium enterprise ${ }^{2}$. The colonial economy of the Estado da Índia in turn benefited from its involvement in the international trade in a high value commodity like opium.

Within a few years of the conquest of Bengal (1757) the East India Company declared a monopoly over the opium produce of the territories it had subjugated. By 1799 it had imposed a system whereby production, processing and sale of the drug was strictly regulated by the Company. From the early 1790 s the East India Company had introduced a policy under which all the opium produced in its territories in Gangetic eastern India was directly appropriated by the Company from the peasant producers. Opium was procured in the raw, semi-liquid, state from poppy cultivators and processed by the Company in its own establishments. Processing mainly involved desiccation, and then packing opium formed into large balls in wooden chests. The bulk of this opium was intended for export, mainly to China. The Company's export opium ('Bengal opium') was auctioned at Calcutta

\footnotetext{
${ }^{1}$ I use this term for Indians or 'natives' of Portuguese India (Índia Portuguesa).

2 See FARO0QUI, Amar. Sindias and the Raj: Princely Gwalior, c.1800-1850. New Delhi: Primus, 2011, chap. IV.
} 
to private dealers who then took the risk of smuggling the drug into China3.

The Qing imperial authorities had imposed a ban on the import of opium into China in 1729. Consequently, the Company preferred to let private traders run the risk of selling the drug at the China-end, rather than carrying opium in its own ships. This was a smuggling venture in China. Nevertheless, this smuggling venture became possible due to the protection that was provided by the East India Company, and the British government. When the Qing authorities threatened to extinguish smuggling of the commodity in the 1830s, by which time it had become a large-scale undertaking, the British promptly sent in armed forces to prevent them from doing so, and thereby uphold the principles of 'free trade'. This led to the First Opium War (1839-42).

The Malwa plateau (located in the western districts of present-day Madhya Pradesh, and south-eastern Rajasthan), also produced (and continues to produce) large quantities of opium. In the colonial period, the Malwa region was entirely under numerous princely states (subject to 'indirect rule'), so that the Company had no direct control over the production of the drug or its wholesale trade. Private Indian and European traders, initially Indo-Portuguese traders from Goa, pioneered the export of the opium produce of Malwa - "Malwa opium" - to China. Sea-borne exports of Malwa opium commenced in the last quarter of the eighteenth century. From 1803 onwards the Company imposed restrictions on the export of opium from the West Coast so as to prevent Malwa opium from competing with the Company's opium in the China market. This was a goal that the Company was unable to attain due to rampant smuggling of the drug through the Gujarat coast. The export trade in Malwa opium continued to expand in the early decades of the nineteenth century. The Company was then forced to give up its objective of having a market exclusively for Bengal opium. Instead, it attempted to establish a monopoly over Malwa opium as well by trying to procure the entire produce of the region, and auctioning it on the pattern of the Bengal opium auctions. Malwa opium auctions commenced in 1821 and were held at Bombay. The auctions were discontinued after 1830 since the

\footnotetext{
${ }^{3}$ Cf. PRAKASH, Om. The New Cambridge History of India, vol. II, part V, European Commercial Enterprise in Pre-Colonial India. Cambridge: Cambridge University Press, 1998, p. $327 \mathrm{ff}$. The following discussion on the East India Company's opium policy in the early nineteenth century is based mainly on FAROOQUI, Amar. Smuggling as Subversion: Colonialism, Indian Merchants and the Politics of Opium. New Delhi: New Age, 1998.
} 
Company was unable to emerge as the sole supplier of the Malwa drug. From 1831 onwards, private traders, both British and Indian, were allowed to export opium via Bombay on the payment of a moderate duty 4 .

The introduction of Malwa opium into the China market created a crisis for the Company as it could no longer hope to be the exclusive supplier of Indian opium. Further, the abolition of the East India Company's monopoly of trade with China led to an increase in the number private traders operating in the South China Sea from 1834 onwards. M ost of these private traders were attracted by the lucrative opium smuggling enterprise centred on Canton. Among the private British firms in China engaged in opium smuggling the two most prominent were Jardine $\&$ Matheson and Dent $\&$ Co. By the 1820 s a substantial portion of the drug sent out from Calcutta and Bombay was consigned to them. Of the two Jardine $\&$ Matheson, the bigger of the two firms, pushed its business more aggressively ${ }^{5}$.

After 1834 there was a sizeable rise in the number of opium chests shipped from India to China. According to figures worked out by Michael Greenberg, the leading historian of the crucial formative phase of the colonial opium venture in China and of the role played by the drug in unleashing the Opium War, exports of Bengal and Malwa opium roughly doubled between $1834 / 5$ and $1838 / 39$, from 21,885 chests to 40,200 chests $^{6}$.

A massive expansion of the market for the drug in China could accommodate both 'brands' of opium. Such an objective could only be achieved by forcing the Chinese imperial authorities to remove restrictions on the opium trade. Seen from this perspective the First Opium War was the initial culmination of a chain of events set in motion by the emergence of Malwa opium as a rival to Bengal opium.

Indian traders in western India had demonstrated great ingenuity and

\footnotetext{
${ }^{4}$ For the Company's early Malwa opium policy see Parliamentary Papers, Select Committee on the Affairs of the East India Company, 1831, vol.VI, Appendix IV (no. 320 D).

${ }^{5}$ The most authoritative study of Jardine \& M atheson is GREENBERG, Michael. British Trade and the Opening of China: Cambridge University Press, Cambridge, 1951. Greenberg's pioneering study was based mainly on the letter-books of Jardine \& M atheson and its predecessor firms. M ore recently, Richard Grace has provided a detailed account of the firm in his biographical study of the two main partners of the firm; see Richard J. Grace. Opium and Empire: The Lives and Careers of William Jardine and James Matheson. Montreal: M cGill Queen's University Press, 2014.

${ }^{6}$ GREENBERG. Loc. cit., Appendix I .Opium in bulk was reckoned in 'chests': one 'chest' of 'Bengal opium' , weighed $160 \mathrm{lbs}$ avoirdupois, net.
} 
resourcefulness in evading the Company's restrictions on the export of Malwa opium by developing a clandestine route for carrying the drug from producing areas to the West Coast for onward shipment to China. The route completely avoided British-administered territories. The main alternative route proceeded from northern Malwa to Pali in Rajasthan; from Pali across the Great Indian Desert to the port of Karachi on the Sind coast; from Karachi by sea to Portuguese Daman. It is pertinent that Daman is located very close to Bombay. The Portuguese imposed no restrictions on the transit of opium through Daman; in fact duties levied on opium imported into and exported from Daman were a source of revenue for the enclave. In official British records the label 'Daman opium' soon became a synonym for smuggled Malwa opium.

The smuggling route remained active till the end of the 1830s and was eventually abandoned after the First Opium War. The Opium War coincided with another event, namely the conquest of Sind by the British. The annexation of Sind in 1843 blocked the route from Rajasthan to Karachi. A reinterpretation of the evidence on the conquest of Sind suggests that 'some correlation existed between British opium policy on the one hand and the decision to annex Sind ${ }^{17}$. With the military occupation of Karachi by British troops in 1839, prior to the annexation of the kingdom, opium supplies to Daman dried up. The early 1840s marked the end of the historically crucial first phase - the smuggling phase of the Malwa opium enterprise.

Narcotrafficking was a source of capital accumulation for the nascent Indian bourgeoisie operating under colonial constraints. Given the restrictions imposed by the East India Company and the remote geographical location of the producing areas, this role might not have been possible without access to the Indian Ocean network of the Estado da Índia via Portuguese Daman. On the other hand, participation in the international trade in opium had far-reaching implications for Portuguese territories in India. This is a subject that requires much further research. One outcome was the greater degree of interaction at

\footnotetext{
${ }^{7}$ MARKOVITS, Claude. The Global World of Indian Merchants, 1750-1947: Traders of Sind from Bukhara to Panama. Cambridge: Cambridge University Press, 2000, p. 41 and n. 23. For an evaluation of the evidence see WONG, J.Y. British Annexation of Sind in 1843: An Economic Perspective. Modern Asian Studies, vol.XXI, no.2, p. 225-244, 1997.
} 
various levels between Portuguese India and British India in the nineteenth century. This increased interaction might partly account for the intellectual ferment in Portuguese India during the latter half of the century. Rochelle Pinto's study of printing and the public sphere in Goa during the post- 1822 period demonstrates that the emergence of a vibrant public sphere in Portuguese India and debates on cultural and political issues were closely linked to intellectual trends in late nineteenth century British India during the early nationalist phase ${ }^{8}$. Such a development assumes a closer relationship between the Portuguese settlements and the British Empire in India than had been possible in the preceding two centuries of relative isolation. The economic integration of the two colonial spaces in the era of opium smuggling created the historical conditions for these developments.

The Portuguese settlements on the West Coast of India should not be viewed in isolation. They were part of a larger Portuguese Indian Ocean network, the latent potential of which came into full play with the opium trade. At one end of this network was the Mozambique-Gujarat link. A number of Gujarat merchants were active in Mozambique as were Indo-Portuguese merchants ${ }^{9}$. Circa 1823, official Daman customs earnings from the trade with Mozambique stood at Rs.25000. This was the second largest source of revenue after opium ${ }^{10}$. Mozambique was an important market for East African slaves in the early nineteenth century ${ }^{11}$. Further, Gujarat supplied cloth to Mozambique in return for slaves and ivory ${ }^{12}$. We shall have more to say on the slave trade a little later. Then there was the commerce between Macau and the Portuguese colonies on western coast of India. Smuggled Malwa opium gave a boost to this commerce. There were a few other branches of this network, as the one between Macau and Timor, in which sandalwood was the main

\footnotetext{
${ }^{8}$ PINTO, Rochelle. Between Empires: Print and Politics in Goa. New Delhi: Oxford University Press, 2007.

${ }^{9}$ PEARSON, M.N. The New Cambridge History of India, vol.I, part I, The Portuguese in India. New Delhi: Orient Longman, 1990, p. 152; Celsa Pinto. Trade and Finance in Portuguese India: A Study of the Portuguese Country Trade, 1770-1840. New Delhi: Concept, p. 59.

108 May 1823, National Archives of India (New Delhi), Separate Revenue (hereafter, SR), 72/17 January 1824.

${ }^{11}$ M.N. PEARSON, op. cit., p.152; CLARENCE-SM ITH, Gervase. The Third Portuguese Empire, 1825-1975: A Study in Economic Imperialism. Manchester: Manchester University Press, 1985, p. 44.

${ }^{12}$ Cf. ALPERS, Edward A. Ivory and Slaves in East Central Africa: Changing Patterns of Trade to the Later Nineteenth Century. London: Heinemann, 1975, chap. IV; CAM PBELL, G. (ed.). The structure of Slavery in the Indian Ocean Africa and Asia. London: Frank Cass, 2004, p. 19-20.
} 
commodity ${ }^{13}$.

The entire network derived from space that Portuguese colonialism had historically appropriated as the first European colonial power in the Indian Ocean. This space was represented in territorial terms by strategically located settlements in the region. It also rested on traditional ties with indigenous and private European participants in Asian seaborne commerce. This is not to suggest that this network was very strong. Quite to the contrary. But it was not extinct. The Portuguese empire in Asia survived by letting out the space that it had appropriated in the Indian Ocean to numerous entrepreneurs who operated in the backwaters of the Company's empire in Asia. These could be Chinese, Gujarati, Parsi or private British traders. Portuguese colonial elites reinforced their own traditional ties with these groups by sharing their space with them in return for a minor share of earnings. They were thereby able to escape complete marginalization in a viciously competitive world. Besides, the Estado da Índia had a prominent non-official counterpart which was not subject to, and usually in defiance of, its authority. This was the underbelly of the Portuguese Indian Ocean Empire. Pirates, brigands, smugglers, adventurers, mercenaries, slave-traders, swindlers, cheats and run-away convicts constituted what has been referred to by George Winius as the Portuguese 'shadow empire' in Asia ${ }^{14}$.

The development of the Malwa opium export trade on the West Coast may be attributed to traders of M acau, Goa and Daman. The origin of the trade dates back to the 1770s when small quantities of the drug might have been supplied to China through Macau ${ }^{15}$. The Company's monopoly over Gangetic opium obviously motivated IndoPortuguese traders to use their contacts in western India to procure Malwa opium. Macau traders had been dealing in Bengal opium during the eighteenth century, and continued to do so, but an alternative source of supply would not have been unwelcome. H.B. Morse in his Chronicles of the East India Company Trading to China refers to a representation made by the Portuguese authorities of Macau in 1804 to the English officials at Canton about

\footnotetext{
${ }^{13}$ CLARENCE-SM ITH, Gervase, op.cit., p. 29.

${ }^{14}$ WINIUS, G. D. The "Shadow Empire" of Goa in the Bay of Bengal. Itinerario, vol.VII, no.2, p. 83-101, July 1983.

15 'Minute', 30 April 1823, SR, 56/12 J une 1823.
} 
the import of Malwa opium from Bombay ${ }^{16}$. What prompted the representation was not the importation of opium from a source other than Gangetic eastern India (this was really a matter of concern for the East India Company rather than the Portuguese authorities), but 'the fact that the opium was discharged and sold at Whampoa, to the detriment of Macao ${ }^{17}$.

More than the Macau Portuguese it was the Indo-Portuguese traders on the West Coast of India who acquired large stakes in the growth of the Malwa opium trade. Being closer to the areas of production, they could pocket larger profits. The Indo-Portuguese traders of the West Coast virtually pioneered large-scale exports of M alwa opium to China in partnership with the Gujarat and Bombay traders at one end and the Macau Portuguese at the other. A leading role was played in this by Rogério de Faria, a native-born IndoPortuguese merchant of Goa. Rogério de Faria was king of the Malwa opium sea-borne trade at the turn of the century. He was part of a group of Indo-Portuguese entrepreneurs who procured Malwa opium from Rajasthani and Gujarati suppliers for onward shipment to Macau. The Indo-Portuguese traders had set up their base at Bombay and/or Daman rather than at Goa since the capital of the Estado da Índia was situated at too great a distance from the main Malwa supply networks.

Portuguese records relating to the opium trade in Daman, Goa, Diu and Macau have only been partially mined. The broad contours of the history of Indo-Portuguese participation in the venture have been outlined in two studies, Celsa Pinto's account of the Portuguese "country" trade in the late eighteenth and early nineteenth centuries and Teotonio de Souza's essay on Rogério de Faria. ${ }^{18}$ Rogério de Faria dominated the opium export trade of the West Coast from the 1790s to the early 1820s and continued to be a prominent merchant even after that till the collapse of his business in the late-1830s. At the beginning of the nineteenth century he shifted his base to Bombay where he served as

\footnotetext{
${ }^{16}$ MORSE, H. B. The Chronicles of the East India Company Trading to China, 1635-1834. Oxford: Clarendon Press, 1926, vol. II, p. 429.

${ }^{17}$ M ORSE, H.B. Ibidem, p.430.

${ }_{18}^{18}$ PINTO, Celsa. Op.cit.; SOUZA, Teotonio R. De, Rogério de Faria: An Indo-Portuguese Trader with China Links. In: MATOS, Artur Teodorio de and THOMAZ, Luís Filipe F. R. (org). Relações entre a Índia Portuguesa, a Ásia do Sudeste, e o Extremo Oriente. Macao/Lisboa: [s.n.], 1993, p. 309-19. Maria Aurora Couto (in her Goa: A Daughter's Story. New Delhi: Penguin, 2004), provides some fascinating information about the Kamat and de Faria families.
} 
a link between Bombay, Daman and Macau. Rogério de Faria extended his commercial links to Brazil as well after 1807, when the Portuguese royal court shifted to Rio de Janeiro, and was appointed Consul for Brazil at Bombay. ${ }^{19}$

Teotonio de Souza discovered a precious private archive that has considerable information on de Faria's commercial activities - the Mhamai papers containing correspondence of the Kamat (Camotim) firm, a prominent Goan business concern. The Mhamai papers are among the holdings of the Xavier Centre of Historical Research, Porvorim (Goa). Unfortunately the Daman customs records (Alfândega de Damão) housed in the Goa State Archives, Panaji (Panjim) remain virtually unexplored. These, along with the Macau correspondence (Correspondência de Macau), can help us figure out the connections between merchants of Bombay, Gujarat, Malwa and Macau in the first half of the nineteenth century. The Portuguese authorities encouraged the export of opium through Daman (and Diu) throughout the period when its passage via Bombay was outlawed by the British, merely imposing a re-export duty on the commodity. Daman was the seat of government of the Estado da Índia's Provincia do Norte, the Northern Province of Portuguese territories on the West Coast of India.

Daman rapidly became the focal point of the Malwa sea-borne trade, eclipsing Goa as a commercial hub for a few decades. Writing about Goa in 1827, Cottineau de Kloguen noted that 'Daman is now not only comparatively, but really more commercial than Goa ${ }^{120}$. Between 1800 and circa 1840 Daman was the economic pivot of the Portuguese colonial empire in Asia. After 1805, once Bombay had to be abandoned by opium exporters, Daman gradually emerged as the main entrepot where opium arriving from the Gujarat and Sind ports was gathered to await shipment to Macau. In 1820 Daman was opened to Portuguese as well as foreign ships for the opium export trade ${ }^{21}$. The Kachchh ports in north-western Gujarat, such as Mandvi and Lakhpat Bandar (besides numerous minor coastal stations), which were still beyond the reach of the Company, and Karachi, were intermediate ports for Daman consignments. In the early twenties Iranian opium was also

\footnotetext{
${ }^{19} \mathrm{Cf}$. PINTO, Celsa. Op. cit., p.59.

${ }^{20}$ Denis L. Cottineau de Klouguen, An Historical Sketch of Goa, the Metropolis and the Settlement in India. New Delhi: Asian Educational Services, 2005 (first published 1831), p. 115.

${ }^{21}$ Copy of provizão dated 26 July 1820, Goa State Archives (Panjim), Monções do Reino, 205-B, fol.702.
} 
brought to Daman from the port of Bushire. There were consignments from Kandahar in Afghanistan as well, 'with notice that any quantity may be supplied from that province'22. It is most likely that some Turkish opium too went to China via Daman ${ }^{23}$.

The Indo-Portuguese traders were favourably placed to mobilize supplies of opium through their long-standing association with Gujarati traders. Celsa Pinto has underlined the multifarious nature of the existing trade between Daman and other parts of Gujarat during our period24. Till about 1815, Gujarati traders primarily acted as agents of IndoPortuguese or indigenous Bombay middlemen for procuring Malwa opium through their traditional networks. The Indo-Portuguese and Macau Portuguese took over once the opium had reached Daman. It is only gradually that the Gujarati (and Rajasthani) dealers learnt of the real value of the commodity and then began supplying it directly to the West Coast shippers. John Dunlop, British collector of Ahmadabad in Gujarat, remarked in 1819,

Until about 4 years ago the merchants of Guzerat [Gujarat] were but little acquainted with the profits, or indeed the destination of the opium which they supplied, to Bombay, or Portugueze merchants, according to the orders they might receive and their profits were confined to the commission of Agents, or at the utmost to driving the best bargain in their power, with those persons whom only they saw in the transaction.

The full value of this drug however soon became known, and about 4 years ago the Guzerattees [Gujaratis] began to contract directly for the delivery of opium to Pattamars or ships, wherever it might be required ... ${ }^{25}$.

Daman assumed even greater significance after 1818 when the Company, following Third Anglo-M aratha War, emerged as a major territorial power in western India and attempted to enforce its ban on opium exports more extensively and rigorously. Simultaneously, as mentioned earlier, from 1821 onwards it began to purchase large quantities of opium directly from the Malwa market. Greenberg has estimated that in the 1820s, when the Company was participating in the Malwa opium trade, as much as two-

22 F. Warden, 'Minute', 30 April 1823, SR, 56/12 June 1823. This is one of the earliest references, as far as I am aware, of the regular production of opium in Afghanistan during the colonial period.

${ }^{23}$ It is worth bearing in mind that when in 1821 the East India Company's medical board at Calcutta undertook a comparative chemical analysis of various varieties of opium marketed in China, samples of Turkish opium were among the five types of the drug (others being varieties produced in India) that were examined to determine their respective narcotic properties. Report of Dr. J. Jameson, secretary to the medical board, Calcutta, SR, 16/30 October 1821.

${ }^{24}$ Celsa Pinto. Op. cit., p.42.

${ }^{25} 1$ November 1819, SR, 8/7 January 1820. 
thirds of the drug was being exported from Daman ${ }^{26}$. By now there were two varieties of Malwa in the market: Company Malwa and Daman Malwa. The Company's Malwa opium had to compete with Daman Malwa opium, while Bengal opium had to compete with both. Indo-Portuguese traders of Daman performed three functions in the sea-borne opium trade. They managed coastal transportation of cargoes from Karachi to Daman; they organized export transactions at Daman (probably as brokers); and they arranged for shipments to China, taking care of various requirements such as payment of customs duties and port clearances. The Daman-Macau segment was, of course handled by indigenous and European traders of Bombay, or the Macau Portuguese ${ }^{27}$.

The Daman supply market was dominated by nine indigenous traders: Modi Dorabji Nasserwanji (Mody Dorabssa Nasservange), Byramji Bhikaji (Beramgi Bicaji), Kavasji Byramji (Caugi Beramgi), Moolchand Heerachand (Mulchand Íra), Karamchand Hurruckchand (Caramchand Arcachande), Manickchand Hurruckchand (Manacchande Arcachand), Dayaram Dulobha (Dearamo Dulobo), Lallubhai Valobdas (Lalú Valobo) and Racique Vallobo. These traders are stated to have been residents of the city28. Most of these names, of persons who imported 'opium on boats by sea, into Demaun, from Kurauchee, Palee, Cutch [Kachchh], and the ports of Scinde [Sind]', are mentioned in a detailed report sent from Daman in 1823 by an informant of the Company. The names of Byramji Bhikaji and Kavasji Bhikaji are omitted in this particular report. Interestingly the information was acquired from Byramji and Kavasji, who appeared to pretend that they themselves did not participate in the trade. Among other things, the informant learnt that shortly 'two ships belonging to Sir Roger de Faria Portuguese are expected from Bombay to take it [opium] to Macau' ${ }^{29}$. One of these ships was the Castro (earlier named Conde do Rio Pardo) that eventually sailed from Daman, according to other sources, on April 29, with 1103 chests valued at Rs.1, 391,940 belonging to Rogério de Faria, Racique Valobo, Caugi Beramgi, Beramgi Bicagi, Dearamo Dulobo, Caromchande Amarchande, Mulchand Íra,

\footnotetext{
${ }^{26}$ M ichael Greenberg. Op. Cit., p.131.

${ }^{27}$ In historical literature the Gujarati component of the Indo-Portuguese traders has received very little attention, as compared to the Goan Indo- Portuguese merchants.

${ }^{28}$ M ONIZ, A. F. Notícias e documentos para a historia de Damão, Antiga Provincia do Norte, Bastora: Typ. Rangel, 1917, vol.IV, p. 82.

${ }^{29} 8$ April 1823, SR, 35/12 June 1823, enclosure.
} 
Manacchand Arcachande, M ody Dorabça Nacervangi and Lalú Valobo ${ }^{30}$.

Dayaram Dulobha had been active in the Daman-Goa trade since the turn of the century. He remained a key figure in the Daman trade throughout our period. The names of Moolchand Heerachand and Karamchand Hurruckchand crop up repeatedly in contemporary records, both Portuguese and British. António Moniz in his historical account of Daman refers to Moolchand Heerachand (Mulchande Íra) as one of those merchants who introduced the opium commerce in the port ${ }^{31}$. Byramji Bhikaji and his son Kavasji Byramji belonged to a family of Parsi priests. The family had settled down in Pune (Poona) in the mid-eighteenth century and later moved to the Portuguese territories in Gujarat. Byramji became a revenue-farmer for some of the petty chiefs in Gujarat. Byramji diversified into commerce and invested money in the opium trade during the twenties. His business was later carried on by his two sons Bhikaji Byramji and Kavasji Byramji. They owned a ship that plied between Daman, Bombay, China and Mozambique ${ }^{32}$. Of the two brothers (Bhikaji and Kavasji), Kavasji was more important in the opium trade.

The stable, but authoritarian and pro-absolutist, administration of Julião José da Silva Vieira who was governador of Daman from the late 1820s to 1834, helped to consolidate the key position of the port on the West Coast. This was a time of prosperity for the city. The affluence of Daman found expression in the construction of new public buildings, as for example the government secretariat (popularly called the torrinha, or gallery). Customs revenues derived from opium made available the finances for this construction activity ${ }^{33}$. Daman was also a centre of ship-building.

Encouragement received from the Portuguese authorities, coupled with facilities they could provide both in western India and at the China end, had lured a large number of opium smugglers and shady operators to Portuguese enclaves. The British authorities repeatedly appealed to the Portuguese government to check the trade, but to little avail. It

\footnotetext{
30 M ONIZ A. F. Notícias e documentos.... Bastora: Typ. Rangel, 1904, vol. II, p.174-75; SIDDIQI, Asiya. The Business World of Jamsetjee Jejeebhoy. In: (ed.). Trade and Finance in Colonial India, 1750-1860. Delhi, Oxford University Press, 1985, p. 197; BULLEY, Anne. The Bombay Country Ships, 1790-1833. Richmond: Curzon, 2002, p. 198.

${ }^{31}$ M ONIZ, A.F. Op. Cit, vol. II, p. 174.

${ }^{32}$ KARAKA, D. F. History of the Parsis. New Delhi: Discovery Publishing House, 1986, vol. II, p. 44-45. See also MONIZ, A. F. Op. Cit., vol. IV, p. 75

${ }^{33}$ M ONIZ, A. F. Notícias e Documentos... Bastora: Typ. Rangel, 1923, vol. I, p. 46-48.
} 
was not till the 1830s, when the Company altered its Malwa opium policy, which allowed the drug to pass through Bombay on the payment of a duty, that the Daman trade declined-but was not immediately abandoned. In China, preference was being increasingly shown for Lintin by a growing number of traders. The Portuguese interlude, though brief, contributed significantly to altering the nature of British involvement in Malwa opium.

In the long run the Estado da Índia could not have sustained the opium trade, especially after Bombay had been opened for private exports of the drug. The economy of Daman, or of the Estado da Índia, was much too weak to be able to compete with Bombay. The financial and commercial infrastructure of Daman was just no match for the facilities available in British India. We also need to bear in mind that as most of the bulk dealers who shipped opium from Daman were based in Bombay, ultimately it was the British colonial port that reaped the benefits of the Daman trade.

The decline of Daman after the mid-1830s was hastened by upheavals in Portuguese India following the absolutist defeat in Portugal in 1833-34 ${ }^{34}$. In the struggle for power in the Portuguese colonies during the early 1830s, against the backdrop of the fierce conflict between liberals and absolutists in Portugal, Rogério de Faria supported the government of Bernardo Peres da Silva that had been ousted at Goa. Peres da Silva was the first Indo-Portuguese Goan to head the government of Portuguese India and was given the designation of prefeito (1834). He was appointed by the regime installed in Portugal in 1834 under Maria II, but was forced to leave Goa by racist-absolutist elements in 1835. Peres da Silva moved to Daman ${ }^{35}$. Here he received the support and financial assistance of de Faria, and with the latter's help formed a provisional government which lasted till 1837. Rogério de Faria was given certain exemptions on customs duties by the new administration. This might have been a desperate attempt on the part of de Faria to recover the business he had lost to Bombay merchants. The plan to restore Peres da Silva's authority at Goa failed and brought about de Faria's bankruptcy in $1838^{36}$.

\footnotetext{
${ }^{34}$ BORDALO, Francisco Maria. Ensaios sobre a Estatística das Possessões Portuguezas no Ultramar: Estado da Índia, part I. Lisbon: Impr. Nacional, 1862, p. 38; DANVERS, F. C. The Portuguese in India. London: Allen, 1966, vol. II, p. 457.

${ }_{35}^{35}$ M ONIZ, A. .F. Notícias e Documentos.... Bastora: Typ. Rangel, 1910, vol. III, p.54 ff. 187, 231; 241.

${ }^{36}$ For details see SOUZA, Teotonio R. de. Op. Cit., p. 309-319.
} 
As we have already noted, the opium trade, especially its smuggling component, reactivated the latent Portuguese sea-borne commercial network in Asia and East Africa. The Indo-Portuguese traders were active participants in exchanges between the Indian sub-continent on the one hand and the Arabian Sea, the Persian Gulf, East Africa and the Eastern M editerranean on the other. Narcotic substances, particularly opium, created, and were part of, a complex web of relationships extending from the Mediterranean and East Africa to the South China Sea. During the first half of the nineteenth century, Indian opium was the single most valuable commodity sustaining these relationships. There was, besides, opium that moved from the Eastern M editerranean to the western coast of India and thence to East Asia (though some of it would have gone directly as well). Turkish and Egyptian varieties were well known in Asia in the early modern period. In the sixteenth century Garcia da Orta referred to the opium of Cairo (Meceri) in his Colloquies, as did his near-contemporary Dutch traveller Linschoten ${ }^{37}$. At the beginning of the nineteenth century, Egyptian opium, known locally as Misree (literally, from M isr or Egypt) was one of the varieties of the drug available at Gujarat ports. This was transported by sea from the Red Sea ports, and some of it was consumed in India itself (mainly in Multan, southern Panjab) ${ }^{38}$. However, it was Turkish opium that figured more prominently than Egyptian opium (or the produce of other parts of the Eastern Mediterranean) in the list of drugs that constituted part of the long-distance trade of the Eastern Mediterranean-Red SeaIndian Ocean-South China Sea networks. As already mentioned earlier, small quantities of opium from Iran, Afghanistan and Turkey were being re-exported via Daman at the peak of the smuggling era. Recent research on the subject would indicate that the smuggling enterprise stimulated opium cultivation in Iran and that the commodity was fairly important for the economy of the area in the latter half of the century ${ }^{39}$.

At the same time the involvement of Indo-Portuguese traders in the opium trade centred on Daman gave a stimulus to the slave trade between East Africa and the western

\footnotetext{
${ }^{37}$ ORTA, Garcia da. Colloquies on the Simples and Drugs of India. Transl. by Clements Markham. London: Henry Sotheran and Co., 1913, p. 332; WATT, George A. A Dictionary of the Economic Products of India. London: W.H. Allen, 1892, vol. VI, part I, p. 35.

${ }^{38}$ Surat collector, 26 September 1803, M aharashtra State Archives M umbai, Revenue Department, 1821/7.

${ }^{39}$ Cf. REGAVAM, Rami. The history of opium in Iran 1850-1955 and its global context. Talk delivered at department of history, University of Delhi, September 17, 2009.
} 
coast of India in the first half of the nineteenth century. We have referred to the Mozambique-Gujarat sector of the slave trade above. While this sector of the trade has been studied by, among others, Edward Alpers and Rudy Bauss, the history of the East Africa-Karachi segment remains somewhat obscure. It is not sufficient to focus on the Gujarat coast to grasp the extent to which the opium trade encouraged the slave trade in the Indian Ocean. The slave trade of the Sind coast was a vital part of the overall trade between India on the one hand and East Africa and the Red Sea on the other. After all southern Sind still has a large, and socially cohesive, community of African slave descent, namely the Sidis ${ }^{40}$. The slave trade of Karachi was flourishing during the $1820 \mathrm{~s}$ and 1830 s. It is no coincidence that these were the decades in which the port began attracting a large business in smuggled opium.

There are frequent references to the slave trade of Karachi in reports prepared by the East India Company's officials on the eve of the annexation of Sind. A report on the port and town of Karachi, written just around the time that the city was occupied by the Company's troops in 1839, mentions two "classes" of slaves brought from Africa, "The Siddees or Africans and Hubshees or Abyssinians [from Ethiopia". According to the report slaves from various parts of the African coast were first brought to M uscat in the Persian Gulf from where they were transported to Karachi to be then "sent up the country for sale ${ }^{\text {"41. }}$. Occasionally there were also slaves from Eastern Europe, Georgians for instance, who were "brought down but only on a private order, their price being too high to admit of any speculations being made in them"42.

The traffickers in human cargo and narcotics reinforced each other, casting their nets very wide, so as to include the eastern Mediterranean in the west and the farther edges of the South China Sea in the east. The clandestine trade in the two commodities

${ }^{40}$ Cf. Amy Catlin-Jairazbhoy and Edward A Alpers, eds., Sidis and Scholars: Essays on African Indians, Delhi/Noida, Rainbow Publishers, 2004; Manish Karmwar, 'African Diaspora in India: A Historical Study', unpublished Ph.D. thesis, Department of African Studies, University of Delhi, Delhi. Alice Albinia's travelogue Empires of the Indus: The Story of a River, London, John Murray, 2008, chap.III, provides valuable sociological insights about the Sidi community of Sind, their memories of their African past, and their assertiveness about the African roots of Sidi identity.

${ }^{41}$ HART, S. V. W. Report on the Town and Port of Kurachee ... etc. (c.1840). In: Selections from the Records of the Bombay Government, new series, vol. XVII, part I. Bombay: Printed for Government at the Bombay Education Society's Press, 1855, p. 220.

${ }^{42}$ Ibidem. 
(for there was British pressure on the Portuguese by the mid-1830s to put an end to the slave trade) moved along channels initially excavated by the Portuguese, large stretches of which often ran dry in the seventeenth and eighteenth centuries, but which witnessed a brief revival in the first half of the nineteenth century. This brief revival eventually benefited British colonialism and, in a subordinate way, Asian indigenous elites, much more than it did the Portuguese economy for reasons that are well known. Nonetheless we are still far from having a comprehensive understanding of the implications of the opium trade of the nineteenth century for Portugal itself.

To conclude, one would like to emphasize the need to be attentive to the histories of the knowledge of narcotics and of medicine, transmission of techniques, modifications of taste, and cultural practices pertaining to intoxication while probing the history of opium in the colonial era. The wide geographical scope of the exchanges involved in moving the commodity from producers to consumers created a historically new situation that has not been adequately explored. The under-developed nature of the historiography of other, non-British, colonialisms in the Indian subcontinent has rendered this task all the more difficult since the Estado da Índia is an absence (as are other non-British, including French, colonial possessions on the Indian subcontinent) in histories of colonial India ${ }^{43}$.

Yet, we need to recover the history of the relationships that linked the IndoPortuguese world to both the Indian subcontinent as well as to the wider world of the seas and oceans if we are to break out of the narrow confines of 'national' histories. It is only then that we might be able to make sense of the histories of people inhabiting spaces

\footnotetext{
${ }^{43}$ The French settlements in India are even more of an absence, in histories of the subcontinent dealing with the colonial period, than Portuguese India. Portuguese colonies are assumed to be frozen in time from around the end of the sixteenth century (this is a narrative that begins, as we all know, in 1498 with the arrival of Vasco da Gama at Calicut/Kozhikode), though they are vaguely recognized as being there and surface occasionally, but inconsequentially, in accounts of western India for the subsequent centuries. The French enclaves are completely forgotten after the mid-eighteenth century, having been visible for a very brief period-less than half a century, c.1700-1750. Going by histories of modern India one would get the impression that the main French colony, Pondichéry, did not have a nineteenth century at all. French Mahé on the Malabar coast is, of course, so remote that even its presence is virtually unknown. Similar is the fate of other French colonies, located closer to Pondichéry. Researchers from mainland India (i.e., that part of the subcontinent which was subjugated to British colonialism) have rarely turned their attention to the history of French possessions in India during the late colonial period. The urban historian Narayani Gupta is the only scholar I am aware of who has studied nineteenth century Pondichéry in some detail, using, I might add, the archives of the Overseas Department at Aix-en-Provence (GUPTA. Pondichéry in the Nineteenth Century: A Port Without a Hinterland. In: Indu Banga, ed. Ports and Their Hinterlands in India (1700-1950). New Delhi: Manohar, 1992, p. 89-101).
} 
without boundaries, as for example the lascars, the quintessential rootless products of sea-dominating colonialisms ${ }^{44}$. In the words of Amitav Ghosh, "The lives of the lascars should be of more interest today than before because they were the first Asians and Africans to participate freely and in substantial numbers in a globalised workspace"45. To know the shadowy world of narcotrafficking in the nineteenth century is, then, to know also the ill-defined world of the lascars and other such people and communities and their historical experiences; their destinies too need to find a place in studies that attempt to explore global history.

To come back to the centrality of opium to the global history of capitalism as an integral part of the histories of other colonial commodities such as tea, sugar and cotton. Opium exports from India to China steadily increased from the 1790s to finance the purchase of Chinese tea by the East India Company for the British market. Simultaneously there was the growth of the export of raw cotton from Bombay to China. By the turn of the century it was no longer necessary to carry bullion to China for the Company's tea investments. The massive increase in the importation of tea into Britain was facilitated by Pitt's Commutation Act of 1784 that substantially lowered duties imposed on the commodity. The expansion of the British market for tea was accompanied by a corresponding increase in the consumption of sugar. Tea and sugar went hand-in-hand. Sidney Mintz has shown that the century from 1750 to 1850 witnessed the "popularization of sweetened tea" in the United Kingdom. ${ }^{46}$ The easily assimilated calories that its consumption provided made it an essential component of the working class diet. He observes that "Children learned the sugar habit at a very tender age: sweetened tea was a part of every meal...." 47

\footnotetext{
${ }^{44}$ Lascar, was the term used for highly skilled non-European sailors of (usually) Asian/East African origin who comprised the subordinate crews of ships plying (mainly) in the Indian Ocean during the eighteenth and nineteenth centuries.

${ }^{45} \mathrm{GHOSH}$, Amitav, 'Of Fanas and Forecastles: The Indian Ocean and Some Lost Languages of the Age of Sail', Economic and Political Weekly, 21 July 2008, p. 58.

${ }^{46}$ MINTZ, Sidney W. Sweetness and Power: The Place of Sugar in Modern History. New York: Penguim, 1986 (first published, 1985), p. 147

${ }^{47}$ Ibidem, p. 143.
} 
At this time Britain obtained most of its sugar from its colonies in the Caribbean where it was produced by slave labour. As we know this slave labour was in turn obtained from Africa through the long-established Atlantic slave trade. The existence of the Atlantic slave trade made possible the use of slave labour on a scale that was unprecedented in modern times, for the production of cotton in the southern states of America. The cotton produced in the southern states of America became the main source of supply of raw material for the Lancashire cotton industry. We have thus two interlinked 'trade triangles': Africa-Caribbean/USA-Britain and India-China-Britain. 'Trade triangle' is however a misnomer, for these are really descriptions of mechanisms for the one-way flow of wealth to the metropolis of which Britain was till the third quarter of the nineteenth century the main global centre.

Data de recebimento do artigo: 05/09/2016

Data de aprovação do artigo: 23/10/2016

\section{References:}

\section{Primary Sources}

National Archives of India, New Delhi, Separate Revenue Consultations.

Goa State Archives, Panaji (Panjim), M onções do Reino.

Maharashtra State Archives M umbai, Revenue Department Consultations.

\section{Bibliography}

ALBINIA, Alice. Empires of the Indus: The Story of a River, London: J ohn Murray, 2008.

ALPERS, Edward A. Ivory and Slaves in East Central Africa: Changing Patterns of Trade to the Later Nineteenth Century, London: Heinemann, 1975.

BORDALO, Francisco Maria. Ensaios sobre a Estatística das Possessões Portuguezas no Ultramar: Estado da Índia, part I, Lisbon: Impr. Nacional, 1862.

BULLEY, Anne. The Bombay Country Ships, 1790-1833, Richmond: Curzon, 2002. 
CAM PBELL, G. (ed.). The Structure of Slavery in the Indian Ocean Africa and Asia, London: Frank Cass, 2004.

CATLIN-JAIRAZBHOY, Amy \& ALPERS, Edward A. (eds.). Sidis and Scholars: Essays on African Indians, Delhi/Noida: Rainbow Publishers, 2004.

CLARENCE-SM ITH, Gervase. The Third Portuguese Empire, 1825-1975: A Study in Economic Imperialism, Manchester: Manchester University Press, 1985.

COTIINEAU DE KLOUGUEN, Denis L. An Historical Sketch of Goa, ... etc., reprint, New Delhi: Asian Educational Services, 2005 (first published 1831).

COUTO, Maria Aurora. Goa: A Daughter's Story, New Delhi: Penguin 2004.

DANVERS, F.C. The Portuguese in India, London: Frank Cass, 1966.

FAR00QUI, Amar. Sindias and the Raj: Princely Gwalior, c.1800-1850, New Delhi: Primus, 2011.

Smuggling as Subversion: Colonialism, Indian Merchants and the Politics of Opium, New Delhi: New Age, 1998.

GHOSH, Amitav. Of Fanas and Forecastles: The Indian Ocean and Some Lost Languages of the Age of Sail', Economic and Political Weekly, 21 July 2008.

GRACE, Richard J. Opium and Empire: The Lives and Careers of William Jardine and James Matheson, Montreal: McGill Queen's University Press, 2014.

GREENBERG, Michael. British Trade and the Opening of China, Cambridge: Cambridge University Press, 1951.

GUPTA, Narayani. 'Pondichéry in the Nineteenth Century: A Port Without a Hinterland', Indu Banga, ed., Ports and Their Hinterlands in India (1700-1950), New Delhi: Manohar, 1992, p.89-101.

HART, S.V.W. 'Report on the Town and Port of Kurachee... etc.' (c.1840), Selections from the Records of the Bombay Government, new series, vol.XVII, part I, Bombay, 1855.

KARAKA, D.F. History of the Parsis, reprint, New Delhi: Discovery Publishing House, 1986.

KARMWAR, Manish. 'African Diaspora in India: A Historical Study', unpublished Ph.D. thesis, Department of African Studies, University of Delhi, Delhi.

MARKOVITS, Claude. The Global World of Indian Merchants, 1750-1947: Traders of Sind from Bukhara to Panama, Cambridge: Cambridge University Press, 2000. 
MINTZ, Sidney W. Sweetness and Power: The Place of Sugar in M odern History, New York: Penguin, 1986 (first published, 1985).

MONIZ, A.F. Notícias e Documentos Para a Historia de Damão, Antiga Provincia do Norte, vol.I, second edition, Bastora: Typ. Rangel, 1923.

. Notícias e Documentos Para a Historia de Damão, Antiga Provincia do Norte, vol.IV, Bastora: Typ. Rangel, 1917.

- Notícias e Documentos Para a História de Damão, Antiga Provincia do Norte, Vol. III, Bastora: Typ. Rangel, 1910.

. Notícias e Documentos Para a Historia de Damão, Antiga Provincia do Norte, vol.II, Bastora: Typ. Rangel, 1904.

MORSE, H.B. The Chronicles of the East India Company Trading to China, 1635-1834, Oxford: Clarendon Press, 1926.

ORTA, Garcia da. Colloquies on the Simples and Drugs of India, tr., Clements Markham, London: Henry Sotheran and Co., 1913.

PRAKASH, Om. The New Cambridge History of India, vol.II, part V, European Commercial Enterprise in Pre-Colonial India, Cambridge: Cambridge Univesity Press, 1998.

Parliamentary Papers, Select Committee on the Affairs of the East India Company, 1831, vol.VI, Appendix IV (no. 320 D).

PEARSON, M.N. The New Cambridge History of India, vol.I, part I, The Portuguese in India, Indian edition, New Delhi: Orient Longman, 1990.

PINTO, Celso. Trade and Finance in Portuguese India: A Study of the Portuguese Country Trade, 1770-1840, New Delhi: Concept Publishers, 1994.

PINTO, Rochelle. Between Empires: Print and Politics in Goa, New Delhi: Oxford University Press, 2007.

REGAVAM, Rami. 'The history of opium in Iran 1850-1955 and its global context', talk delivered at Department of History, University of Delhi, 17 September 2009.

SIDDIQI, Asiya. 'The Business World of Jamsetjee Jejeebhoy', in Asiya Siddiqi, ed., Trade and Finance in Colonial India, 1750-1860, Delhi: Oxford University Press, 1985.

SOUZA, Teotonio R. de. 'Rogério de Faria: An Indo-Portuguese Trader with China Links', in Artur Teodorio de Matos and Luís Filipe F.R. Thomaz, eds., Relações entre a Índia 
Portuguesa, a Ásia do Sudleste, e o Extremo Oriente, Macao/Lisbon, 1993, pp. 30919.

WATT, George A. A Dictionary of the Economic Products of India, vol.VI, London: W.H. Allen, 1892.

WINIUS, G.D. 'The "Shadow Empire" of Goa in the Bay of Bengal', Itinerario, vol.VII, no.2, July 1983, pp.83-101.

WONG, J.Y. 'British Annexation of Sind in 1843: An Economic Perspective', Modern Asian Studies, vol.XXI, no.2, 1997, pp.225-44. 